\title{
KEMAMPUAN PRODUSEN TEMPE KEDELAI DALAM MENERAPKAN SNI 3144:2009
}

\section{Soybean Tempeh Producers Capability in Implementing SNI 3144:2009}

\author{
Ellia Kristiningrum dan Danar Agus Susanto
}

\author{
Pusat Penelitian dan Pengembangan Standardisasi, Badan Standardisasi Nasional \\ Gedung BPPT I Lantai 13, M.H. Thamrin No. 8,Jakarta, Indonesia \\ e-mail: ellia@bsn.go.id
}

Diterima: 12 November 2014, Direvisi: 5 Februari 2015, Disetujui: 13 Februari 2015

\begin{abstract}
Abstrak
Indonesia merupakan negara produsen tempe terbesar di dunia dan menjadi pasar kedelai terbesar di Asia. Sebanyak 50\% dari konsumsi kedelai Indonesia digunakan untuk memproduksi tempe, 40\% untuk tahu, dan $10 \%$ untuk produk lain (seperti tauco, kecap, dan lain-lain). Dukungan yang diberikan pemerintah untuk mendorong daya saing produksi tempe kedelai salah satunya adalah dengan menetapkan Standar Nasional Indonesia (SNI) tempe kedelai yaitu SNI 3144:2009. Kesesuaian produk tempe dengan standar dapat melindungi kesehatan konsumen, menjamin perdagangan pangan yang jujur dan bertanggung jawab, diversifikasi/pengembangan produk dan mendukung perkembangan industri tempe kedelai. Penelitian ini bertujuan untuk menganalisis kemampuan produsen tempe dalam memenuhi persyaratan SNI 3144:2009 - tempe kedelai. Penelitian ini dilakukan dengan cara mengujikan 55 sampel produk tempe di laboratorium yang terakreditasi oleh KAN. Penentuan jumlah sampel dilakukan dengan menggunakan metode Slovin terhadap jumlah Primkopti yang ada di masing-masing wilayah. Sedangkan untuk teknik samplingnya menggunakan teknik acak lengkap sederhana. Kesimpulan yang peroleh dari penelitian ini adalah masih banyak produsen tempe yang belum dapat menerapkan SNI 3144:2009 untuk parameter kadar air, kadar lemak, kadar protein, dan serat kasar. Parameter kadar lemak menjadi parameter yang paling sulit untuk dipenuhi oleh produsen tempe kedelai.
\end{abstract}

Kata kunci: produsen tempe kedelai, SNI 3144:2009, penerapan standar.

\begin{abstract}
Indonesia is the largest soybean tempeh producer in the world and the largest soybean markets in Asia. As many as $50 \%$ of Indonesian soybean consumption is used to produce tempeh, $40 \%$ for tofu, and $10 \%$ for other products (such as tauco, ketchup, etc.). The supports given by the government to boost the competitiveness of soybean tempeh one of which was established the Indonesian National Standard (SNI) for soybean tempeh that is SNI 3144: 2009. Conformity of tempeh to standard can protect the health of consumers, ensure fair and responsible food trade, product diversification/development and supporting the development of soybean tempeh industry. This study aims to analyze the ability of producers to meet the requirements of SNI 3144: 2009 - soybean tempeh. This research was done by testing out of 55 samples of soybean products in laboratories accredited by KAN. Determination on number of samples is done by slovin methode against number of Primkopti in each region. As for the sampling technique used was simple random sampling technique. The conclusions obtained from this study is there are still many tempeh producers who have not been able to implement SNI 3144: 2009 for these parameters: water content, fat content, protein content, and fiber. fulfilment of fat content is the most difficult parameters to be met by the producers.
\end{abstract}

Keywords: soybean tempeh producers, SNI 3144:2009, standard implementation.

\section{PENDAHULUAN}

Tempe adalah salah satu makanan khas Indonesia. Di tanah air, tempe sudah lama dikenal selama berabad - abad silam dan dikonsumsi secara turun temurun, khususnya di daerah Jawa dan telah berkembang di hampir seluruh wilayah di Indonesia. Tempe adalah makanan yang dibuat dari fermentasi terhadap biji kedelai atau beberapa bahan lain yang menggunakan beberapa jenis kapang Rhizopus, seperti Rhizopus oligosporus, Rh. oryzae, $R h$. stolonifer (kapang roti), atau Rh. arrhizus.

Indonesia merupakan negara produsen tempe terbesar di dunia dan menjadi pasar kedelai terbesar di Asia. Sebanyak 50\% dari 
konsumsi kedelai Indonesia dilakukan untuk memproduksi tempe, $40 \%$ tahu, dan $10 \%$ untuk produk lain (seperti tauco, kecap, dan lain-lain). Tempe banyak dikonsumsi di Indonesia, tetapi sekarang telah mendunia. Akibatnya sekarang tempe diproduksi di banyak tempat di dunia, tidak hanya di Indonesia. Berbagai penelitian terkait produk tempe telah dilakukan di sejumlah negara, seperti Jerman, Jepang, dan Amerika Serikat. Tempe mulai menjadi perhatian masyarakat ilmiah ketika diselenggarakannya suatu simposium yang disponsori oleh PBB yaitu International Symposium on Indigenous Fermented Foods (SIFF). Kegiatan tersebut diselenggarakan bersamaan dengan the Fifth International Conference on the Global Impacts of Applied Microbiology (GIAM V) di Bangkok, November 1977 yang dihadiri oleh lebih 450 ilmuwan tekenal dari seluruh dunia.

Gerakan tempe mendunia terjadi karena didorong oleh berbagai faktor, selain faktor ilmiah. Faktor tersebut ada sejak tahun 1983 diantaranya, (1) tempe mulai populer di Amerika dan Eropa, (2) Kegiatan KOPTI, suatu asosiasi pembuat tempe di Indonesia, (3) tumbuhnya masyarakat pengikut diet Jepang di internasional dan (4) Meningkatnya gambaran positif pentingnya makanan dari kedelai sebagai sumber pangan dengan kandungan nutrisi tinggi (BSN, 2011).

Sebagai salah satu makanan khas Indonesia dan mulai mendunia, pemerintah memberikan dukungan untuk mendorong daya saing produksi tempe kedelai salah satunya adalah dengan menetapkan Standar Nasional Indonesia (SNI) tempe kedelai yaitu SNI 3144:2009. Dukungan itu berlanjut dengan perjuangan mengusulkan standar tempe menjadi standar regional Asia untuk menjadikan tempe sebagai bagian industri pangan penting di Indonesia. Indonesia berhasil mengusulkan standar tempe menjadi new work di sidang ke 34 Codex Alimentarius Commission yang berlangsung di Jenewa, Swiss pada tanggal 4-9 Juli 2011. Selanjutnya new work tersebut diadopsi dalam Draft Report of The Sixty Fifth Session of The Executive Committee of The Codex Alimentarius Commission. (BSN, 2011)

Dengan adanya dukungan tersebut, peluang untuk mengangkat industri tempe ke dunia menjadi terbuka. Mengingat di dunia, orang yang menganut vegetarian jumlahnya mencapai 500 juta orang, maka konsumen dan calon konsumen tempe sangat besar, baik dalam negeri atapun luar negeri. Produk tempe menjadi produk pengganti daging ketika kaum vegetarian mencari sumber protein. Hal ini akan menjadi prospek bisnis yang baik. Standar akan 100 menjadikan daya saing produk menjadi lebih tinggi serta dapa tmempengaruhi keberterimaan produk (Setiadi, 2012).

Dalam penyusunan standar internasional produk tempe kedelai, Indonesia menjadi salah satu negara yang mendapatkan tugas untuk menyusunnya, sehingga kesempatan terbuka untuk menyesuaikan dengan kemampuan produsen tempe dalam negeri dan SNI tempe kedelai yang telah dimiliki (Setiadi, 2012).

Untuk mendukung hal tersebut, perlu diketahui terlebih dahulu kemampuan produsen tempe lokal dalam memenuhi persyaratan SNI 3144:2009 - tempe kedelai. Tujuan dari penelitian ini adalah menganalisis kemampuan produsen tempe dalam memenuhi persyaratan SNI 3144:2009 - tempe kedelai.

\section{TINJAUAN PUSTAKA}

Standar merupakan alat strategis dan pedoman untuk membantu perusahaan mengatasi tantangan yang paling menuntut dalam bisnis modern serta berguna untuk memastikan operasi bisnis seefisien mungkin, meningkatkan produktifitas, dan membantu perusahaan mengakses pasar yang baru (ISO, 2015). Standar akan menjadi salah satu alat penting untuk pertumbuhan ekonomi nasional dan strategi konvensional bisnis. (Shin DH., Kim H., Hwang J, 2015). Produsen tempe kedelai lokal (varietas Grobogan) telah dapat memproduksi tempe kedelai yang memenuhi persyaratan dalam SNI, kecuali kadar serat kasar (Kumalasari. R, 2012).

\subsection{Sejarah dan Perkembangan Tempe}

Kata tempe diduga berasal dari bahasa Jawa Kuno. Pada zaman Jawa Kuno terdapat makanan berwarna putih terbuat dari tepung sagu yang disebut tumpi. Tempe segar yang juga berwarna putih terlihat memiliki kesamaan dengan makanan tumpi tersebut. Selain itu terdapat rujukan mengenai tempe dari tahun 1875 dalam sebuah kamus bahasa JawaBelanda. Sumber lain mengatakan bahwa pembuatan tempe diawali semasa era Tanam Paksa di Jawa. Pada saat itu, masyarakat Jawa terpaksa menggunakan hasil pekarangan, seperti singkong, ubi dan kedelai, sebagai sumber pangan. Selain itu, ada pula pendapat yang mengatakan bahwa tempe mungkin diperkenalkan oleh orang-orang Tionghoa yang memproduksi makanan sejenis, yaitu koji kedelai yang difermentasikan menggunakan kapang aspergillus. Selanjutnya, teknik 
pembuatan tempe menyebar ke seluruh Indonesia, sejalan dengan penyebaran masyarakat jawa yang bermigrasi ke seluruh penjuru tanah air (Wikipedia, 2012).

\subsection{Tempe di Indonesia}

Indonesia merupakan negara produsen tempe terbesar di dunia dan menjadi pasar kedelai terbesar di Asia. Sebanyak 50\% dari konsumsi kedelai Indonesia dilakukan untuk memproduksi tempe, $40 \%$ tahu, dan $10 \%$ untuk produk lain (seperti tauco, kecap, dan lain-lain). Konsumsi tempe rata-rata per orang per tahun di Indonesia saat ini diperkirakan sekitar 6,45 kg (Wikipedia, 2012).

Salah satu keputusan dari 8th Southeast Asia Soy Foods Seminar and Trade Show yang dilaksanakan di Westin Resort Nusa Dua Bali pada tgl 21-23 Mei 2013 dan dihadiri oleh sekitar 250 orang dari 13 negara, adalah pengakuan bahwa tempe merupakan warisan budaya bangsa Indonesia yang telah diakui dunia sebagai pangan sehat. Salah satu bentuk pengakuan dunia terhadap tempe adalah diterimanya usulan Indonesia oleh FAO dan WHO untuk penetapan Standar Codex Tempe.

Tempe dan hasil olahannya memiliki potensi untuk menjadi produk unggulan Indonesia untuk diekspor ke berbagai belahan dunia; kripik tempe, tepung tempe, cheese steak tempe, nugget tempe, sosis tempe, dan puluhan produk olahan lainnya memiliki potensi sebagai produk unggulan bangsa Indonesia.

Standar teknis untuk tempe kedelai telah ditetapkan dalam Standar Nasional Indonesia SNI 3144:2009 dan berlaku sejak 9 Oktober 2009. Dalam standar tersebut, tempe kedelai didefinisikan sebagai produk yang diperoleh dari fermentasi biji kedelai dengan menggunakan kapang rhizopus sp., berbentuk padatan kompak, berwarna putih sedikit keabu-abuan dan berbau khas tempe.

\subsection{Tempe di Luar Indonesia}

Referensi dan artikel - artikel mengenai tempe telah ditulis diantara tahun 1875 - 1950 oleh orang - orang Eropa, sebagian besar orang Jerman. Industri tempe di Eropa pertama kali dimulai di wilayah Belanda oleh imigran dari Indonesia. Pada tahun 1895, Prinsen Geerlings (ahli kimia dan mikrobiologi dari Belanda) melakukan usaha yang pertama kali untuk mengidentifikasi kapang tempe. Melalui Belanda, tempe telah populer di Eropa sejak tahun 1946 dan mulai meningkat selama tahun 1960 an. (William $S$ dan Akiko A, The Book of Tempeh 2nd ed, 2001).

Selain di Eropa, tempe juga berkembang di Australia, Amerika Serikat, Kanada dan Jepang. Industri tempe di luar Indonesia yang terbesar dalam memproduksi tempe disajikan pada Tabel 1, sebagai berikut:.

Tabel 1 Pembuat tempe terbesar di dunia.

\begin{tabular}{lllcc}
\hline \multirow{2}{*}{ Nama Perusahaan } & \multirow{2}{*}{ Negara } & \multirow{2}{*}{$\begin{array}{c}\text { Tahun } \\
\text { Mulai }\end{array}$} & \multicolumn{2}{c}{ Produksi Rata-rata per Minggu } \\
\cline { 4 - 5 } & & & Lb/week & Kg/week \\
\hline Marusan-Ai & Japan & 1983 & 15.148 & 6.885 \\
Tempe production inc. & Netherlands & 1969 & 13.200 & 6.000 \\
Quong Hop/Pasific Tempeh & USA/CA & 1980 & 7.000 & 3.182 \\
White wave & USA/CO & 1979 & 5.850 & 2.659 \\
Soyfoods unlimited & USA/CA & 1981 & 5.800 & 2.636 \\
Torigoe flour milling & JApan & 1983 & 5.770 & 2.623 \\
The tempeh works & USA/MA & 1979 & 5.500 & 2.500 \\
Marukin foods & Japan & 1983 & 4.620 & 2.100 \\
\hline
\end{tabular}

Sumber: Shurtleff. W, Aoyagi. A, 2001.

\subsection{Primer Koperasi Produsen Tahu tempe Indonesia (Primkopti)}

Primkopti merupakan sebuah perkumpulan koperasi yang merupakan wadah satu-satunya untuk menghimpun dan menggerakkan daya kreasi dan potensi serta membina produsen pengolah bahan makanan dari kedelai yang terdiri dari pengrajin tempe, tahu dan makanan sejenisnya yang berada di wilayah Jakarta Pusat yang terdiri dari 699 anggota. Primkopti hanya mempunyai susunan organisasi tingkat primer yang dikembangkan dari ide dan kebulatan tekad produsen/pengrajin tempe tahu pada tanggal 11 Maret 1979 yang juga ditetapkan sebagai hari lahir Primkopti. Primkopti tersebar di sebagian 
besar wilayah Indonesia dan yang paling besar Primkopti di Pulau Jawa. ada di Pulau Jawa. Berikut adalah jumlah

Tabel 2 Jumlah Primkopti di pulau Jawa.

\begin{tabular}{llc}
\hline No & Wilayah (Propinsi) & Jumlah Primkopti \\
\hline 1 & DKI Jakarta & 5 \\
2 & Banten & 5 \\
3 & Jawa Barat & 25 \\
4 & Jawa Tengah & 35 \\
5 & Jawa Timur & 43 \\
6 & DI Yogjakarta & 5 \\
\hline Jumlah & 118 \\
\hline
\end{tabular}

Sumber: Primer Koperasi Tempe Tahu Tempe Jakarta, 2011.

\subsection{SNI 3144:2009 - Tempe Kedelai}

Definisi tempe kedelai menurut SNI 3144:2009 adalah produk yang diperoleh dari fermentasi biji kedelai dengan menggunakan kapang Rhizopus sp., berbentuk padatan kompak, berwarna putih sedikit keabu-abuan dan berbau khas tempe. Syarat mutu tempe kedelai sesuai Tabel 3 di bawah ini.

Tabel 3 Syarat mutu tempe kedelai.

\begin{tabular}{llll}
\hline No. & Kriteria Uji & Satuan & Persyaratan \\
\hline 1 & Keadaan & & \\
1.1 & Bau & - & normal, khas \\
1.2 & Warna & - & normal \\
1.3 & Rasa & - & normal \\
2 & Kadar air (b/b) & $\%$ & maks. 65 \\
3 & Kadar abu (b/b) & $\%$ & maks. 1,5 \\
4 & Kadar lemak (b/b) & $\%$ & min. 10 \\
5 & Kadar protein $(\mathrm{N} \mathrm{x} \mathrm{6,25)} \mathrm{(b/b)}$ & $\%$ & min. 16 \\
6 & Kadar serat kasar (b/b) & $\%$ & maks. 2,5 \\
7 & Cemaran logam & & \\
7.1 & Kadmium (Cd) & $\mathrm{mg} / \mathrm{kg}$ & maks. 0,2 \\
7.2 & Timbal (Pb) & $\mathrm{mg} / \mathrm{kg}$ & maks. 0,25 \\
7.3 & Timah (Sn) & $\mathrm{mg} / \mathrm{kg}$ & maks. 40 \\
7.4 & Merkuri (Hg) & $\mathrm{mg} / \mathrm{kg}$ & maks. 0,03 \\
8 & Cemaran arsen (As) & $\mathrm{mg} / \mathrm{kg}$ & maks. 0,25 \\
9 & Cemaran mikroba & & \\
9.1 & Bakteri coliform & APM/g & maks. 10 \\
9.2 & Salmonella sp. & - & negatif/25 g \\
\hline
\end{tabular}

Sumber: BSN, 2009.

\section{METODE PENELITIAN}

\subsection{Metode Pengumpulan Data}

Metode pengumpulan data dilakukan dengan cara mengujikan sampel produk tempe di 102 laboratorium yang terakreditasi oleh KAN. Jumlah keseluruhan sampel yang diuji adalah 55 sampel.

Penentuan jumlah sampel dilakukan menggunakan metode Slovin dengan memperhatikan jumlah Primkopti yang ada di 
masing-masing wilayah. Metode ini digunakan karena ukuran populasi telah diketahui (Amirin. Tatang. M, 2011), yaitu jumlah Primkopti di masing-masing wilayah. Metode ini memberikan kebebasan dalam menentukan nilai batas kesalahan yang diasumsikan (Setiawan. N, 2007), sehingga dikarenakan terbatasnya waktu dan biaya penelitian maka ditetapkan galatnya 10\% (tingkat kepercayaan 90\%).

Dalam penelitian ini, kemampuan yang dimiliki oleh produsen tempe diasumsikan homogen dalam hal bahan baku, proses pembuatan dan pengemasan, sehingga pengambilan sampelnya menggunakan teknik

Tabel 4 Jumlah sampel kajian.

\begin{tabular}{llcc}
\hline No & Wilayah (Propinsi) & $\begin{array}{c}\text { Jumlah } \\
\text { Primkopti }\end{array}$ & $\begin{array}{c}\text { Jumlah Sampel } \\
\text { (Slovin/ TK 90\%) }\end{array}$ \\
\hline 1 & DKI Jakarta & 5 & 2 \\
2 & Banten & 5 & 2 \\
3 & Jawa Barat & 25 & 12 \\
4 & Jawa Tengah & 35 & 16 \\
5 & Jawa Timur & 43 & 20 \\
6 & DI Yogjakarta & 5 & 3 \\
\hline \multicolumn{2}{l}{ Jumlah } & 118 & 55 \\
\hline
\end{tabular}

\subsection{Metode Analisa Data}

Metode analisa data yang digunakan adalah metode analisa deskriptif, yaitu analisa mendasar untuk menggambarkan keadaan data secara umum (Wiyono, 2011). Dalam penelitian ini, data yang dianalisa adalah data hasil pengujian sampel tempe kedelai untuk selanjutnya digunakan sebagai indikator untuk mengukur kemampuan produsen dalam menerapkan SNI tempe kedelai.

\subsection{Jenis dan Sumber Data}

Data primer dalam pengkajian ini merupakan data yang didapatkan dari hasil pengujian sampel tempe kedelai yang dilakukan oleh laboratorium Balai Besar Industri Agro (BBIA Bogor), Balai Besar Teknologi Pencegahan Pencemaran Industri (BBTPPI Semarang), Balai Riset dan Standardisasi Surabaya (Baristand Surabaya). Sedangkan sampel produk diambil dari wilayah Jawa Barat, DKI Jakarta, Banten, Jawa Tengah, DI Yogyakarta, dan Jawa Timur.

\subsection{Ruang Lingkup Penelitian}

Ruang lingkup dalam penelitian ini dilakukan untuk membatasi cakupan pembahasan yaitu sampel tempe diambil dari produsen di wilayah DKI Jakarta, Banten, Jawa Timur, Jawa Barat, Jawa Tengah, dan Daerah Istimewa Yogyakarta. acak lengkap sederhana (Martadiputra. BAP, 2015).

Cara pengambilan sampel uji tempe kedelai dilakukan berdasarkan SNI 19-0428-1989 - Petunjuk Pengambilan Contoh Padatan (BSN, 2009). Contoh uji diambil dalam keadaaan bobot basah (tempe segar) yang diperoleh dari produsen tempe kedelai. Sedangkan cara uji keadaan sampel yang meliputi kadar air, abu, protein, lemak dan serat kasar sesuai dengan SNI 01-2891-1992 - Cara uji makanan dan minuman.
Pengujian dan analisa dilakukan terhadap 4 parameter kritis (critical point) persyaratan SNI 3144:2009 yaitu kadar air, kadar protein, kadar lemak dan serat kasar.

\section{HASIL DAN PEMBAHASAN}

\subsection{Pengambilan dan Pengujian Sampel Produk Tempe Kedelai}

Pengambilan sampe tempe kedelai dilakukan di perwakilan Primkopti masing-masing wilayah di pulau Jawa. Total sampel yang diujikan sebanyak 55 sampel. Banyaknya sampel yang diambil untuk masing-masing pelaku usaha disesuaikan dengan ketentuan pengambilan sampel yang ada dalam SNI 3144:2009 tempe kedelai. Kondisi sampel yang diambil adalah sampel tempe kedelai segar yang siap untuk dipasarkan (kurang lebih berumur 3 hari setelah proses produksi). Kemasan tempe kedelai tidak dipersyaratkan, sampel dengan kemasan daun atau plastik bisa diambil. Sampel tempe kedelai diuji di 3 (tiga) laboratorium yang telah diakreditasi KAN untuk ruang lingkup pengujian proksimat (kadar air, kadar lemak, serat kasar, kadar protein) di 3 (tiga) kota yang berbeda, yaitu Bogor, Semarang dan Surabaya. Sampel dari masing-masing daerah dikirim ke laboratorium sesaat setelah diambil dengan ketentuan sebagai berikut: 
Tabel 4 Laboratorium pengujian yang digunakan untuk menguji sampel tempe kedelai.

\begin{tabular}{|c|c|c|c|}
\hline No & Sampel Dari Propinsi & Nama Lab Uji & Alamat \\
\hline 1 & DKI Jakarta dan Banten & Balai Besar Industri Agro (BBIA) Bogor & $\begin{array}{l}\text { Jl. Ir. H. Juanda } 11 \\
\text { Bogor } 16122\end{array}$ \\
\hline 2 & Jawa Barat & Balai Besar Industri Agro (BBIA) Bogor & $\begin{array}{l}\text { Jl. Ir. H. Juanda } 11 \\
\text { Bogor } 16122\end{array}$ \\
\hline 3 & Jawa Tengah & $\begin{array}{l}\text { Laboratorium Pengujian Limbah dan } \\
\text { Lingkungan dan Aneka Komoditi: Balai } \\
\text { Riset dan Standardisasi Industri dan } \\
\text { Perdagangan Semarang }\end{array}$ & $\begin{array}{l}\text { Jl. Ki Mangunsarkoro } \\
6 \text {, Semarang }\end{array}$ \\
\hline 4 & Jawa Timur & $\begin{array}{l}\text { Balai Riset dan Standardisasi Industri } \\
\text { dan Perdagangan Surabaya }\end{array}$ & $\begin{array}{l}\text { Jl. Jagir Wonokromo } \\
360 \text { Surabaya }\end{array}$ \\
\hline 5 & DI Yogyakarta & Balai Besar Industri Agro (BBIA) Bogor & $\begin{array}{l}\text { Jl. Ir. H. Juanda } 11 \\
\text { Bogor } 16122\end{array}$ \\
\hline
\end{tabular}

\subsection{Hasil Pengujian Produk Tempe Kedelai} Pengujian yang dilakukan terhadap 55 sampel tempe kedelai yang mewakili daerah DKI
Jakarta, Banten, Jawa Barat, Jawa Tengah, DI Yogyakarta, Jawa Timur menunjukkan hasil sebagai berikut:

Tabel 5 Hasil pengujian pada sampel tempe kedelai dari wilayah DKI Jakarta dan Banten.

\begin{tabular}{llcccccc}
\hline No & $\begin{array}{c}\text { Parameter SNI 3144:2009 } \\
\text { Tempe Kedele }\end{array}$ & Satuan & $\begin{array}{c}\text { Persyaratan } \\
\text { dalam SNI }\end{array}$ & \multicolumn{3}{c}{ Hasil Pengujian } \\
\hline 1 & Kadar air & $\%$ & Maks. 65 & 65,7 & S 2 & S 3 & S 4 \\
\hline 2 & Kadar protein & $\%$ & Min. 16 & 17,1 & 16,9 & 17,1 & 16,7 \\
3 & Kadar lemak & $\%$ & Min. 10 & 10,3 & 10,7 & 8,98 & 8,17 \\
4 & Serat kasar & $\%$ & Maks. 2,5 & 1,62 & 1,93 & 2,11 & 3,08 \\
\hline
\end{tabular}

Catatan : Blok warna merah menandakan hasil uji tidak sesuai SNI 3144:2009 Tempe Kedele.

Sumber : Data diolah, 2012.

Tabel 6 Hasil pengujian pada sampel tempe kedelai dari wilayah Jawa Barat.

\begin{tabular}{|c|c|c|c|c|c|c|c|c|c|c|c|c|c|c|c|}
\hline \multirow{2}{*}{ No } & \multirow{2}{*}{$\begin{array}{c}\text { Parameter } \\
\text { SNI } \\
3144: 2009\end{array}$} & \multirow{2}{*}{ Satuan } & \multirow{2}{*}{$\begin{array}{l}\text { Persyaratan } \\
\text { dalam SNI }\end{array}$} & \multicolumn{12}{|c|}{ Hasil Pengujian } \\
\hline & & & & s 1 & s 2 & s 3 & s 4 & S 5 & s 6 & s 7 & S 8 & S 9 & S10 & s11 & $\mathrm{S} 12$ \\
\hline 1 & Kadar air & $\%$ & Maks. 65 & 67,5 & 67,5 & 64,1 & 64 & 66,1 & 66,2 & 66,1 & 66,2 & 65,6 & 66,7 & 65,2 & 66 \\
\hline 2 & $\begin{array}{l}\text { Kadar } \\
\text { protein }\end{array}$ & $\%$ & Min. 16 & 15,6 & 16,9 & 18,2 & 18,6 & 17,3 & 17,5 & 17,7 & 16,6 & 17,3 & 16,8 & 17,5 & 17,2 \\
\hline 3 & Kadar lemak & $\%$ & Min. 10 & 8,54 & 9,75 & 10,7 & 12,8 & 10,4 & 9,14 & 9,9 & 8,96 & 9,52 & 9,55 & 7,72 & 7,57 \\
\hline 4 & Serat kasar & $\%$ & Maks. 2,5 & 3,44 & 2,4 & 2,37 & 0,77 & 2,16 & 2,45 & 2,58 & 1,85 & 5,02 & 1,9 & 2,11 & 2,72 \\
\hline
\end{tabular}

Catatan : Blok warna merah menandakan hasil uji tidak sesuai SNI 3144:2009 Tempe Kedele.

Sumber : Data diolah, 2012.

Tabel 7 Hasil pengujian pada sampel tempe kedelai dari wilayah Jawa Timur.

\begin{tabular}{|c|c|c|c|c|c|c|c|c|c|c|c|c|c|c|c|c|c|c|c|c|c|c|c|}
\hline \multirow{2}{*}{ No } & \multirow{2}{*}{$\begin{array}{c}\text { Parameter SNI } \\
\text { 3144:2009 }\end{array}$} & \multirow{2}{*}{ Satuan } & \multirow{2}{*}{$\begin{array}{r}\text { Persyaratan } \\
\text { dalam SNI }\end{array}$} & \multicolumn{20}{|c|}{ Hasil Pengujian } \\
\hline & & & & S 1 & S 2 & S 3 & S 4 & 55 & 56 & S 7 & 58 & S 9 & $\mathrm{~S} 10$ & $\mathrm{~S} 11$ & $\mathrm{~S} 12$ & S 13 & S 14 & S 15 & 516 & S 17 & S18 & S19 & $\mathrm{S} 20$ \\
\hline 1 & Kadar air & $\%$ & Maks. 65 & 64,3 & 59,8 & 66,5 & 59,4 & 66 & 64,6 & 66,9 & 63,3 & 61,2 & 64,6 & 60,2 & 64 & 63 & 63 & 65,5 & 63,9 & 62,8 & 60 & 64,5 & 60,5 \\
\hline 2 & Kadar protein & $\%$ & Min. 16 & 14,3 & 12,7 & 13,4 & 16,5 & 14,1 & 13,7 & 14,4 & 14,4 & 14,5 & 12,9 & 14,6 & 14,4 & 15,2 & 14,6 & 13,2 & 13,4 & 14,9 & 17,5 & 14,2 & 15,3 \\
\hline 3 & Kadar lemak & $\%$ & Min. 10 & 7,7 & 8,9 & 9,3 & 6,9 & 7,8 & 6,9 & 6,9 & 9,9 & 8,4 & 7 & 6,4 & 9,1 & 6,9 & 6,9 & 7 & 10,1 & 3,2 & 3,5 & 4,2 & 5,3 \\
\hline 4 & Serat kasar & $\%$ & Maks. 2,5 & 5 & 1,6 & 1,6 & 2,4 & 5,5 & 2,1 & 9,2 & 2,1 & 6,6 & 3,9 & 0,1 & 2,5 & 7,2 & 0,9 & 3,5 & 4,9 & 9,4 & 9,7 & 9,4 & 6,8 \\
\hline
\end{tabular}

Catatan : Blok warna merah menandakan hasil uji tidak sesuai SNI 3144:2009 Tempe Kedele.

Sumber : Data diolah, 2012. 
Tabel 8 Hasil pengujian pada sampel tempe kedelai dari wilayah Jawa Tengah.

\begin{tabular}{|c|c|c|c|c|c|c|c|c|c|c|c|c|c|c|c|c|c|c|c|}
\hline \multirow{2}{*}{ No } & \multirow{2}{*}{$\begin{array}{c}\text { Parameter SNI } \\
\text { 3144:2009 }\end{array}$} & \multirow{2}{*}{ Satuan } & \multirow{2}{*}{$\begin{array}{r}\text { Persyaratan } \\
\text { dalam SNI }\end{array}$} & \multicolumn{16}{|c|}{ Hasil Pengujian } \\
\hline & & & & s 1 & S 2 & s 3 & S 4 & S 5 & S 6 & s 7 & S 8 & s 9 & s10 & S11 & $\mathrm{S} 12$ & S 13 & S 14 & S 15 & S 16 \\
\hline 1 & Kadar air & $\%$ & Maks. 65 & 66,7 & 63,49 & 64,83 & 66,02 & 67,38 & 66,64 & 63,74 & 61,57 & 65,06 & 66,37 & 66,91 & 66,64 & 66,44 & 64,07 & 66,02 & 67,4 \\
\hline 2 & Kadar protein & $\%$ & Min. 16 & 17,69 & 19,72 & 17,97 & 17,55 & 15,32 & 16,55 & 18,65 & 19 & 17,86 & 17,13 & 16,96 & 15,63 & 15,87 & 18,93 & 17,56 & 15,9 \\
\hline 3 & Kadar lemak & $\%$ & Min. 10 & 9,65 & 9,66 & 9,77 & 9,59 & 9,61 & 9,8 & 8,9 & 9,91 & 10,43 & 9,66 & 9,17 & 9,01 & 8,01 & 9,6 & 9,69 & 7,82 \\
\hline 4 & Serat kasar & $\%$ & Maks. 2,5 & 3,5 & 3,52 & 13,14 & 4,6 & 4,89 & 3,86 & 4,49 & 4,96 & 4,47 & 3,58 & 3,68 & 5,13 & 4,7 & 4,05 & 4,46 & 5,32 \\
\hline
\end{tabular}

Catatan : Blok warna merah menandakan hasil uji tidak sesuai SNI 3144:2009 Tempe Kedele

Sumber : Data diolah, 2012.

Tabel 9 Hasil pengujian pada sampel tempe kedelai dari wilayah DIY.

\begin{tabular}{llccccc}
\hline No & \multirow{2}{*}{$\begin{array}{c}\text { Parameter SNI } \\
\text { 3144:2009 }\end{array}$} & Satuan & $\begin{array}{c}\text { Persyaratan } \\
\text { dalam SNI }\end{array}$ & & \multicolumn{3}{c}{ Hasil Pengujian } \\
\cline { 5 - 7 } & & $\%$ & Maks. 65 & 61 & 64,5 & 67,8 \\
\hline 1 & Kadar air & $\%$ & Min. 16 & 19 & 17 & S 3 \\
2 & Kadar protein & $\%$ & Min. 10 & 15,1 & 8,65 & 8,44 \\
3 & Kadar lemak & $\%$ & Maks. 2,5 & 3,56 & 3,73 & 2,61 \\
\hline
\end{tabular}

Catatan : Blok warna merah menandakan hasil uji tidak sesuai SNI 3144:2009 Tempe Kedele. Sumber : Data diolah, 2012.

Rangkuman hasil pengujian 55 sampel dari daerah DKI Jakarta, Banten, Jawa Barat, Jawa
Tengah, DI Yogyakarta, Jawa Timur sebagai berikut:

Tabel 11 Hasil pengujian tempe kedelai berdasarkan SNI 3144:2009 (Tempe kedelai).

\begin{tabular}{clccc}
\hline No & Parameter & SNI & $\begin{array}{c}\text { Jumlah Sampel } \\
\text { Memenuhi }\end{array}$ & $\begin{array}{c}\text { Jumlah Sampel } \\
\text { Tidak Memenuhi }\end{array}$ \\
\hline 1 & Kadar air & Maks. 65 & $26(47 \%)$ & $29(53 \%)$ \\
2 & Kadar protein & Min. 16 & $31(56 \%)$ & $24(44 \%)$ \\
3 & Kadar lemak & Min. 10 & $8(15 \%)$ & $47(85 \%)$ \\
4 & Serat kasar & Maks. 2,5 & $20(36 \%)$ & $35(64 \%)$ \\
\hline
\end{tabular}

Dari 4 parameter dalam SNI yang diuji, terlihat bahwa banyak produsen yang belum dapat memenuhi persyaratan parameter kadar air, kadar protein, kadar lemak, dan serat kasar.

Persyaratan kadar air tidak dapat dipenuhi oleh sampel dikarenakan sampel mempunyai kadar air yang lebih tinggi dari persyaratan dalam standar. Hal ini dimungkinkan dikarenakan kelembaban udara pada saat fermentasi terlalu tinggi atau dapat juga dikarenakan proses perebusan kedelai yang terlalu lama. Akibat dari hal ini adalah tempe akan cepat rusak. Oleh karena itu, pengaturan suhu udara dan lamanya waktu perebusan sangat diperlukan untuk mengatur nilai kadar air dari tempe yang dihasilkan. Pengaturan suhu dan kelembaban ini dengan alat ukur suhu (thermometer) dan kelembaban (hygrometer) yang diletakkan di ruangan fermentasi sehingga temperatur dan kelembaban udara dapat terpantau dengan baik.

Kadar air kedelai pada saat sebelum fermentasi mempengaruhi pertumbuhan kapang. Selama proses fermentasi akan terjadi perubahan pada kadar air dimana setelah 24 jam fermentasi, kadar air kedelai akan mengalami penurunan menjadi sekitar $61 \%$ dan setelah 40 jam fermentasi akan meningkat lagi menjadi $64 \%$ (Sudarmaji dan Markakis, 1977 dalam Kasmidjo,1990).

Pemenuhan persyaratan kadar protein dan kadar lemak dipengaruhi oleh kualitas bahan baku (air dan kedelai) yang digunakan. Selama proses fermentasi, kedelai akan mengalami perubahan baik fisik maupun kimianya. Protein kedelai dengan adanya aktivitas proteolitik kapang akan diuraikan menjadi asan-asam amino, sehingga nitrogen terlarutnya akan mengalami peningkatan. Dengan adanya 
peningkatan dari nitrogen terlarut maka $\mathrm{pH}$ juga akan mengalami peningkatan. Nilai $\mathrm{pH}$ untuk tempe yang baik berkisar antara 6,3 sampai 6,5. Kedelai yang telah difermentasi menjadi tempe akan lebih mudah dicerna. Selama proses fermentasi karbohidrat dan protein akan dipecah oleh kapang menjadi bagian-bagian yang lebih mudah larut, mudah dicerna dan ternyata bau langu dari kedelai juga akan hilang. Menurut Hidayat dkk (2006), dalam proses fermentasi, kapang membutuhkan oksigen yang cukup untuk memacu pertumbuhannya. Apabila kadar oksigen kurang, pertumbuhan kapang pada substrat lambat. Dalam proses fermentasi Rhizopus oligosporus mensintesis enzim pemecah protein (protease) lebih banyak, sedangkan Rhizopus oryzae lebih banyak mensintesis enzim pemecah pati (alfa-amilase). Tempe yang dihasilkan Rhizopus oryzae tampak lebih padat dibandingkan dengan kapang Rhizopus oligosporus. Apabila yang diutamakan peningkatan nilai gizi protein kedelai, penggunaan Rhizopus oligosporus berperan dalam hal tersebut (Hidayat, dkk. 2006).

Cara pemasakan (perebusan/ pengukusan) mempengaruhi kehilangan protein selama proses pembuatannya. Semakin lama pengukusan semakin banyak protein yang hilang. Antara pengukusan dan perebusan tidak jauh berbeda dalam kehilangan proteinnya. Dengan cara pengukusan akan lebih cepat kering dibandingkan dengan perebusan.

Pemenuhan persyaratan serat kasar dalam tempe dipengaruhi oleh adanya penambahan bahan baku selain kedelai. Dari informasi yang dihimpun selama pelaksanaan kajian, terdapat beberapa produsen yang menambahkan bahan lain selain kedelai (misalnya jagung, ketela, dll) sebagai bahan baku pembuatan tempe. Tentu saja hal ini dilakukan untuk menekan biaya produksi. Namun, terdapat juga produsen yang murni menggunakan bahan baku kedelai, air dan ragi saja untuk pembuatan tempe, sehingga kualitas dan kemurnian tempe terjaga sesuai dengan permintaan pelanggannya.

\section{KESIMPULAN}

Kesimpulan yang peroleh dari penelitian ini adalah masih banyak produsen tempe yang belum dapat menerapkan SNI 3144:2009 untuk parameter kadar air, kadar lemak, kadar protein, serat kasar. Parameter kadar lemak menjadi parameter yang paling sulit untuk dipenuhi oleh produsen tempe kedelai. Presentase parameter lain yang tidak dapat dipenuhi berturut-turut adalah serat kasar, kadar air dan kadar protein.

\section{UCAPAN TERIMA KASIH}

Kami mengucapkan terima kasih yang sebesarbesarnya kepada Manajemen Puncak BSN dan Kepala Pusat Penelitian dan Pengembangan BSN, yang telah mendukung, menyetujui judul dan pendanaan penelitian ini pada tahun 2012. Terima kasih yang sebesar-besarnya juga tidak lupa kami sampaikan kepada segenap tim besar, personel Puslitbang BSN lain dan para narasumber yang telah membantu dari awal hingga akhir penelitian pada forum-forum rapat diskusi dan pengambilan data lapangan.

\section{DAFTAR PUSTAKA}

Agrina-online. (2010). Tempe Naik Pangkat. Diakses Desember 2011 dari http://www.agrinaonline.com/show_article.php?rid=10\&aid= 2447.

Anggraini Diana. (2011). PRIMKOPTI (Primer Koperasi Produsen Tahu tempe Indonesia) Jakarta. Diakses Desember 2011 dari http://didublog.blogspot.com/2011/11/prim kopti-primer-koperasi-produsen.html. Diakses pada Juni 2014.

Amirin. Tatang. M. (2011). Populasi dan Sample Penelitian 4: Ukuran Sampel dan Rumus Slovin. Diakses Desember 2011 dari https://id.scribd.com/doc/64539362/Popula si-Dan-Sampel-Penelitian-4-UkuranSampel-Rumus-Slovin-Tatangmanguny-sBlog.

Astuti M, Meliala A, S Fabien, Mark L. (2010). Tempe, a nutritious and healthy food from Indonesia. Asia Pacific Journal of Clinical Nutrition, Volume 9, Issue 4, Hal 322-325.

Badan Standardisasi Nasional. (2011). Standar Tempe Usulan Indonesia Di Terima Sidang CODEX sebagai New Work Item untuk Standar Regional. Diakses Desember 2011 dari: http://www.bsn.go.id. (2011). SNI 3144:2009 : Tempe Kedele, Jakarta

Hering, L., Bisping, B. and Rehm, H.J. (1990). Fatty acid composition during tempe fermentation. Second Asian Symposium on Non-Salted Soybean Fermentation. Jakarta, Februari 1990.

Hidayat dkk. (2006). Mikrobiologi industri. Andi offset, Yogyakarta. 
Ikehata, H. Wakaizumi, M. and Murata, K. (1968). Antioxidant and Antihemolytic Activity of $A$ new Isoflavon Isolated from Tempeh. Agri. Biol. Chem 32.

Kasmidjo.R.B. (1990). Tempe: Mikrobiologi dan Biokimia Pengolahan Serta Pemanfaatannya. Pusat Antar Universitas Pangan dan Gizi. UGM. Yogyakarta.

Kumalasari. R. (2012). Pengaruh Konsentrasi Inokulum terhadap Kualitas Tempe Kedelai (Glycinemax (L.) Merr) Var. Grobogan. Diakses Januari 2012 dari http://repository.uksw.edu/bitstream/12345 6789/2251/1/T1_652008022_Abstract.pdf

Martadiputra, BAP. (2015). Populasi dan Sample. Diakses Januari 2012 dari http://file.upi.edu/Direktori/FPMIPA/JUR. PEND._MATEMATIKA/196412051990031 BAMBANG_AVIP_PRIATNA_M/MENENT UKAN_UKUTRAN_SAMPEL.pdf

Murata, K. (1985). Formation of antioxidants and nutrient in tempe. Asian Symposium on Non Salted Soybean Fermentation. Tsukuba, Japan

Murakami, H, Asakawa,T., Terao, $J$ and Matsushita, S. (1984). Antioxidative stability of tempeh and liberation of isoflavones by fermentation. Agric. Biol Chem 48.

Messina, M.J., Persky,V,Setchell,K.R.D and Barnes,S. (1994). Soy Intake and Cancer Risk.

Murata K, Ikehata H, Miyamoto T.(1967). Studies on the nutritional value of tempeh. J Food Sci 1967; 32: 580-586.
Primer Koperasi Tempe Tahu Tempe Jakarta. (2011) Daftar Pengrajin Tempe Kedelai di Wilayah Jakarta.

Primer Koperasi Tempe Tahu Tempe Kabupaten Bogor (2011) Daftar Pengrajin Tempe Kedelai di Wilayah Bogor.

Primer Koperasi Tempe Tahu Tempe Surabaya. (2011) Daftar Pengrajin Tempe Kedelai di Wilayah Surabaya

------. (2011). Hasil Pengujian Sampel Tempe Kedelai dari Kabupaten Bogor, Bogor

Sarwono, B. (1982) Membuat tempe dan oncom. PT. Penebar Swadaya, Jakarta, Hal. 1015.

(2011) Hasil Pengujian Sampel Tempe Kedelai dari Daerah Jakarta Pusat. Jakarta.

Setiadi, B. (2012) Menjadikan Tempe sebagai Pangan Dunia, Diakses Januari 2012 dari http://www.forumtempe.org/index.php/id/in formasi/artikel/51-menjadikan-tempesebagai-pangan-dunia

Setiawan, N. (2007). Penentuan Ukuran Sampel Memakai Rumus Slovin dan Tabel KrejcieMorgan:Telaah Konsep dan Aplikasinya. Universitas Padjadjaran. Bandung.

Shurtleff. W, Aoyagi. A. (2001). The Book of Tempeh.

Wikipedia (2011) Tempe Kedelai, Diakses Januari 2011 dari: http://id.wikipedia.org/wiki/tempe.

Wiyono. G. (2011). Merancang Penelitian Bisinis dengan Alat Analisis SPSS 17.0 \& SmartPLS 2.0, Cetakan Pertama, UPP STIM YKPN, Yogyakarta. 
